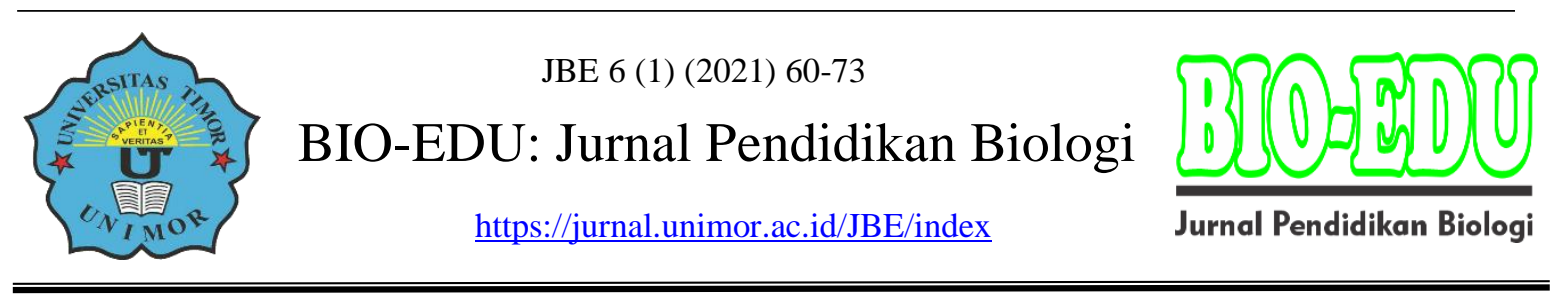

\title{
Etnobotani Tumbuhan Obat Tradisional di Desa Huilelot dan Desa Uiasa Kecamatan Semau Kabupaten Kupang
}

\author{
Fransina Thresiana Nomleni ${ }^{1}$, Yanti Daud ${ }^{1}$, Ferdi Tae ${ }^{1}$ \\ ${ }^{1}$ Program studi pendidikan Biologi, Universitas Kristen Artha wacana Kupang \\ nomlenifince@gmail.com
}

DOI: https://doi.org/10.32938/jbe.v6i1.993

\begin{abstract}
Abstrak
Masyarakat Desa Huilelot dan Desa Uiasa memiliki pengetahuan pengobatan tradisional dengan menggunakan berbagai jenis tumbuhan berkhasiat obat yang berada disekitar mereka mulai dari pekarangan rumah, kebun, pinggir jalan sampai ke hutan. Dari Informasi yang diperoleh maka penelitian ini bertujuan untuk mengetahui jenis tumbuhan yang berkhasiat obat, bagian/organ tumbuhan yang berkhasiat obat, cara pengolahan, penyakit yang disembuhkan dengan menggunakan tumbuhan obat oleh masyarakat dan pembudidayaan tumbuhan berkashiat obat di Desa Huilelot dan Desa Uiasa. Penelitian ini dilakukan pada bulan Oktober - November 2017. Metode yang digunakan dalam penelitian ini adalah jelajah, sedangkan pengambilan sampel dan pengumpulan data tumbuhan obat dilakukan dengn metode eksplorasi di sekitar lokasi. Prosedur kerja meliputi persiapan yang terdiri dari observasi, penentuan informan, dan mempersiapkan alat dan bahan penelitian. Tahap pelaksanaannya terdiri dari wawancara, eksplorasi dan dokumentasi dan identifikasi. Teknik analisis data menggunakan analisis deskriptif, yang disajikan dalam bentuk tabel kemudian mencocokkan tumbuhan dengan gambar atau contoh sesuai sumber pustaka. Berdasarkan hasil penelitian diperoleh 31 jenis tumbuhan berkhasiat obat yang digunakan oleh masyarakat. Organ tumbuhan yang digunakan adalah daun, batang, buah, biji, umbi, akar dan semua organ. Bagian yang paling banyak digunakan adalah daun. Cara meramu yaitu direbus, ditumbuk, dikunyah, makan langsung, diris, diblender dan direbus. Cara meramu lebih banyak dengan cara direbus. Penyakit yang dapat disembuhkan antara lain Darah tinggi, gula darah, usus, kudis, lever, sakit perut, hernia, lambung, keputihan, gondok, malaria dan panas, tumor kandungan, kanker dan tumor payudara, sakit saat bersalin, rematik, ginjal, kencing batu, kencing manis, mata rabun, luka sayatan, pendarahan, dan patah tulang atau kecelakaan. Dari hasil penelitian terdapat 12 jenis yang dibudidayakan di rumah maupun di kebun, sedangkan 19 jenis lainnya tumbuh liar (padang) atau tidak dibudidayakan oleh masyarakat.
\end{abstract}

Kata Kunci: Etnobotani, tumbuhan berkasiat obat, Desa Huilelot, Desa Uiasa.

\begin{abstract}
The Communities in Huilelot and Uiasa Village have the knowledge of traditional medicine by using various types of plants that have medicinal ingridient around them starting from the yard of the house, garden, roadside to the forest. From the Information obtained, this study was aim to determine the types of plants that have medicinal ingridient, medicinal parts/organs of medicinal properties, methods of treatment, diseases that are cured by using medicinal plants by the community and the cultivation of medicinal plants in Huilelot and Uiasa village. This research was conducted in October - November 2017. The method used in this study was roaming, while sampling and data collection of medicinal plants was carried out by exploration methods around the site. The Work procedures include preparation consisting of observation, determination of informants, and preparing tools and research materials. The implementation phase consists of interviews, exploration and documentation and identification. The data analysis technique used was descriptive analysis, which was presented in the form of a table then matches plants with images or examples according to the source of the literature. Based on the results of the study,
\end{abstract}


31 types of plants with medicinal properties were used by the community. Plant organs used were leaves, stems, fruits, seeds, tubers, roots and all organs. The most widely used part is leaves. The method of concocting is boiling, pounding, chewing, eating directly, trimming, blending and boiling. Most of mixing methode used was boiled. Diseases that can be cured include high blood pressure, blood sugar, intestines, scabies, liver, abdominal pain, hernias, stomach, vaginal discharge, goiter, malaria and heat, uterine tumors, cancer and breast tumors, pain during childbirth, rheumatism, kidney, urine stones, diabetes, myopic eyes, cuts, bleeding, and broken bones or accidents. From the results of the study there were 12 species cultivated at home and in the garden, while 19 other species grew wild (sabana) or not cultivated by the community

Keywords: Ethnobotany, plant maedicine Huilelot, and Uiasa Village

\section{PENDAHULUAN}

Provinsi Nusa Tenggara Timur merupakan salah satu daerah yang memiliki keanekaragaman hayati dimana terdapat berbagai jenis tumbuhan dengan berbagai potensi yaitu salah satu sebagai tumbuhan berkhasiat obat. Obat tradisional adalah bahan atau ramuan bahan alam yang berasal dari tumbuhan yang secara turun-temurun telah digunakan untuk pengobatan berbagai jenis penyakit berdasarkan pengalaman. Pengetahuan tradisional yang dimiliki suatu suku atau etnis tersebut diwariskan secara turun-temurun, antara lain penggunaan tumbuhan sebagai obat tradisional (Willa, 2017).

Obat merupakan benda atau zat yang dapat digunakan untuk melawan atau mengobati penyakit dalam tubuh. Obat ialah suatu bahan atau panduan bahan-bahan yang dimasukan untuk digunakan dalam mencegah, mengurangi, menghilangkan, menyembuhkan penyakit atau gejala penyakit, luka atau kelainan badaniah dan rohaniah pada manusia atau hewan dan untuk memperelok atau memperindah badan atau bagian badan manusia. Obat dapat berguna untuk menyembuhkan jenis-jenis penyakit yang diderita oleh manusia. Pada perkembangan sekarang ini, obat dapat dibagi menjadi 2 golongan besar, yakni: 1). Obat modern adalah obat yang dibuat menggunakan teknologi mesin. Obat modern biasanya diproduksi di perusahaan-perusahaan farmasi dengan bahan kimia dan mempunyai satu keunggulan dibandingkan dengan obat tradisional, yakni lebih steril dan lebih terjaga kebersihannya. 2). Obat Tradisional adalah obat-obatan yang diolah secara tradisional, turun-temurun, berdasarkan resep nenek moyang, adat-istiadat, kepercayaan, atau kebiasaan setempat melalui pengetahuan tradisional (Anief, 2002).

Data Riset Kesehatan Dasar (Riskesdas) 2013, suatu penelitian kesehatan berskala nasional yang diselenggarakan Badan Penelitian Dan Pengembangan Kesehatan Kementrian Kesehatan menunjukan bahwa 30,4\% rumah tangga di Indonesia memanfaatkan pelayanan kesehatan tradisional. Dibandingkan obat-obat modern, memang obat tradisional memiliki beberapa kelebihan seperti yang dijelaskan oleh (Mulyati dkk, 2004), antara lain: Pertama, Efek samping obat tradisional relatif kecil bila digunakan secara benar dan tepat baik takaran, waktu dan cara penggunaan, pemilihan bahan serta penyesuai dengan indikasi tertentu. Obat tradisional adalah obat yang berasal dari tumbuh-tumbuhan yang sudah ada sejak zaman dahulu digunakan untuk menjaga kesehatan, menyembuhkan penyakit, dan pemulihan setelah sakit berat atau melahirkan. Jika obat ini telah digunakan secara turun-temurun oleh suatu kelompok masyarakat untuk pengobatan maka obat tersebut merupakan obat tradisional bagi kelompok tersebut (Dalimartha, 2008).

Masyarakat pedesaan umumnya memilih mengunakan obat tradisional dibandingkan obat modern, yaitu: 1). Pada umumnya, harga obat-obatan pabrik sangat mahal, sehingga masyarakat mencari alternatif pengobatan yang lebih murah; 2). Efek samping yang ditimbulkan oleh obat tradisional sangat kecil dibanding obat modern; 3 ). 
Kandungan unsur kimia yang terkandung di dalam obat tradisional sebenarnya menjadi dasar pengobatan kedokteran modern. Artinya, pembuatan obat-obat pabrik menggunakan rumus kimia yang telah disintesis dari kandungan bahan alami ramuan tradisional (Salan, 2009). Obat tradisional ini diperoleh salah satunya adalah tumbuhan. Tumbuhan obat merupakan tumbuhan yang berkhasiat obat yang dapat menggilangkan rasa sakitt, meningkatkan daya tahan tubuh, membunuh bibit penyakit dan memperbaiki organ yang rusak seperti ginjal, jantung, dan paru-paru (Darsini, 2013). Dari zaman dahulu nenek moyang Indonesia telah mengenal teknik pengobatan dengan memanfaatkan tumbuhan yang ada dihutan maupun tumbuhan yang ada disekitar pekarangan rumah dan mengobati berbagai penyakit baik penyakit luar maupun penyakit dalam. Pengetahuan tentang tanaman berkhasiat obat diperoleh dari pengalaman dan keterampilan yang secara turun-temurun telah diwariskan dari satu generasi ke generasi berikutnya (Sari,2006).

Dari teori dan hasil observasi maka perlu dilakukan penelitian untuk mengkaji tentang studi etnobotani dari masyarakat yang masih memiliki pengetahuan pemanfaatan tumbuhan sebagai obat tradisional. Pengetahuan ini masih dimiliki oleh masyarakat desa Huilelot dan desa Uiasa. Masyarakat desa Huilelot dan desa Uiasa memiliki kebudayaan yang cukup tinggi, terbukti dari banyaknya penggunaan tumbuhan sebagai obat tradisional baik itu akar, batang, daun, bunga, buah, kulit batang, kulit buah atau semua organ tumbuhan. Salah satu contoh tumbuhan yang biasa digunakan oleh masyarakat yaitu tumbuhan pepaya, yang dikonsumsi untuk menghilangkan sakit malaria dan demam. Dalam pemanfaatan dan pengolahan tumbuhan obat disetiap daerah bersifat khas dan berbeda berdasarkan pengetahuan dan pengalaman serta kebudayaan di masing-masing daerah. Berdasarkan observasi yang dilakukan peneliti, diketahui bahwa banyak masyarakat yang menggunakan tumbuhan sebagai obat, tetapi belum ada data empiris tentang jenis-jenis tumbuhan obat yang digunakan. Fakta tersebut menunjukan bahwa pengobatan tradisional memiliki arti penting yaitu mendukung kehidupan dan mempunyai potensi yang progresif untuk dikembangkan hal ini sejalan dengan penelitian (Kandowangko dkk, 2011). Sejalan juga dengan penelitian (Herbi, 2015) bahwa bagian tanaman obat yang bisa digunakan berupa akar, kulit batang, kayu bunga atau bijinya. Hal Didukung juga oleh Walujo (2011) tumbuhan obat berakhasiat untuk dapat mengilangkan rasa sakit, meningkatkan daya tahan tubuh, membunuh bibit penyakit dan dapat memperbaiki organ yang rusak seperti ginjal, jantung dan paru-paru.

Dengan demikian penelitian etnobotani perlu dilakukan, agar masyarakat mengetahui tumbuhan-tumbuhan yang biasa dijadikan sebagai obat. Walaupun banyak tumbuhan obat sering dijumpai di lingkungan sekitar, akan tetapi masih banyak tumbuhan yang belum diketahui sebagai obat. Selanjutnya melalui penelitian ini dapat meningkatkan kesadaran masyarakat untuk merawat, menjaga serta melestarikan tumbuhan yang berfungsi sebagai obat. Penelitian ini bertujuan untuk mengetahui jenis tumbuhan yang berkhasiat obat, bagian/organ tumbuhan yang berkhasiat obat, cara pengolahan, penyakit yang disembuhkan dengan menggunakan tumbuhan obat oleh masyarakat dan pembudidayaan tumbuhan berkashiat obat di Desa Huilelot dan Desa Uiasa. 


\section{METODE}

Metode yang digunakan adalah Survey Esporatif, teknik pengumpulan data dengan wawancara semi struktural untuk mengetahui tumbuhan obat yang digunakan dan metode jelajah untuk mengetahui tumbuhan obat dan identifikasi nama ilmiah. Penelitian ini dilaksanakan pada bulan Oktober-November 2017 di Desa Huilelot dan Desa Uiasa Kecamatan Semau Kabupaten Kupang, Provinsi Nusa Tenggara Timur.

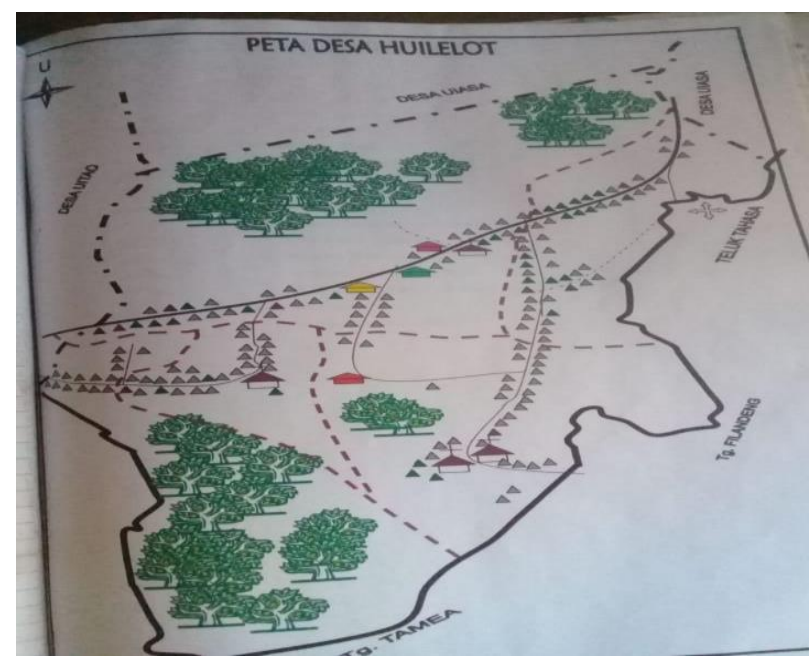

Gambar 1. Peta Desa Huilelot (Sumber: kantor Desa, 2017)

Teknik Pengambilan Sampel yakni Penentuan sampel untuk responden dilakukan dengan teknik purposive sampling. Objek penelitian ini adalah semua spesimen tumbuhan obat dan responden terdiri dari 30 orang (pengobat tradisional 10 orang, 20 orang pasien atau masyarakat yang mengetahui tentang tumbuhan obat. Prosedur penelitian yaitu observasi, mempersiapkan alat yang digunakan, melakukan wawancara dengan responden, pengambilan sampel dilakukan dengan eksplorasi/penjelajahan di lokasi penelitian berdasarkan data yang diperoleh dari informan, selanjutnya bagian tumbuhan yang digunakan sebagai obat diambil menggunakan alat yang disiapkan dalam penelitian. Data yang diperoleh dianalisis secara deskriptif kualitatif menggunakan Kitab Tanaman berkhasiat obat pengarang Herbie, disajikan dalam bentuk tabel yang memuat jenis tumbuhan, bagian tumbuhan, jenis penyakit, cara pengolahan hingga menghasilkan ramuan, manfaatnya serta pembudidayaan.

\section{HASIL DAN PEMBAHASAN}

Desa Huilelot dan Desa Uiasa merupakan dua wilayah yang terletak di Kecamatan Semau, Kabupaten Kupang. Desa Huilelot memiliki luas wilayah $4 \mathrm{~km}$, yang terbagi atas 5 dusun, 5 rukun warga (RW), dan 10 rukun tetangga (RT), jumlah penduduk Desa Huilelot adalah 1.024 jiwa dengan jumlah kepala keluarga 212 pada tahun 2016. Secara administratif Desa Huilelot memiliki batas wilayah sebelah Timur berbatasan degan Laut Kupang dan, bagian Barat berbatasan dengan Desa Uitao, bagian Utara berbatasan dengan Desa Uiasa, dan bagian Selatan berbatasan dengan Laut Selatan. Desa Uiasa memiliki luas wilayah $30.000 \mathrm{~m} 2,5$ dusun, 5 rukun rarga (RW), dan 10 rukun tetangga (RT), jumlah penduduk Desa Uiasa pada tahun sebanyak 1.094 jiwa yang terdiri dari laki-laki 578 jiwa dan perempuan 516 jiwa yang berasal dari 256 kepala keluarga. 
Secara administratif Desa Uiasa memiliki batas wilayah sebelah Utara berbatasan dengan Selat Kupang, sebelah Selatan berbatasan dengan Desa Huilelot, sebelah Timur berbatasan dengan desa Hansisi, dan sebelah Barat berbatasan dengan Desa Letbaun.

Masyarakat Desa Huilelot dan Desa Uiasa pada umumnya masih memilih untuk menggunakan tumbuhan sebagai obat tradisional karena sebagian dari masyarakat sudah terbiasa dengan pengobatan tradisional dan juga dikarenakan ekonomi masyarakat yang rendah. Selain itu keunggulan dari penggunaan obat tradisional adalah bahan baku yang digunakan mudah diperoleh, dapat dibudidayakan sendiri, harganya murah dan dapat diramu atau diolah sendiri. Desa Huilelot dan Desa Uiasa memiliki banyak perbukitan dan hutan sehingga tumbuhan obat masih banyak ditemukan, dan juga akses jalan yang masih kurang bagus sehingga menyulitkan masyarakat untuk berobat pada pengobatan modern oleh karena susahnya transportasi dan jalan yang berlubang-lubang. Hal inilah yang menyebabkan masyarakat di Desa Huilelot dan Desa Uiasa lebih memilih menggunakan berbagai jenis tumbuhan sebagai obat dalam menyembuhkan berbagai penyakit. Dari hasil penelitian terdapat 31 jenis tumbuhan obat yang ditemukan di desa Huilelot dan desa Uiasa. Pengobatan dengan tumbuhan tradisional merupakan bagian dari sistem budaya masyarakat yang potensi manfaatnya sangat besar dalam pembangunan kesehatan masyarakat.

Melalui wawancara dengan para responden diketahui bahwa, pada umumnya bagian organ tumbuhan yang sering digunakan sebagai obat yaitu daun, bunga, buah, kulit batang, umbi, rimpang atau semua organ tumbuhan. Namun, dalam pengolahan dan pemanfaatan tumbuhan obat di setiap daerah bersifat khas dan berbeda berdasarkan pengetahuan dan pengalaman di masing-masing tempat. Masyarakat Desa Huilelot dan Desa Uiasa pada umumnya telah mengenal pengobatan tradisional. Ada beberapa jenis tumbuhan yang sudah sejak lama digunakan dalam proses penyembuhan oleh masyarakat kedua Desa ini antara lain, dalam proses penyembuhan penyakit mencret lendir masyarakat menggunakan air rebusan batang jarak pagar (Jatropha curcas) yang kemudian airnya diminum. Untuk sakit ngilu atau rematik masyarakat menggunakan daun kelor (Moringa olivera) yang diblender atau dihaluskan lalu ditempel, sedangkan sakit pasca melahirkan rebus kulit batangnya untuk diminum. Untuk penyakit deman/malaria masyarakat menggunakan air rebusan daun pepaya (Carica papaya L.) dan kemudian air rebusannya diminum. Untuk luka sayatan masyarakat menggunakan daun Ajeran (Bidens pilosa L.) yang ditumbuk dengan garam lalu ditempelkan pada luka.

Pengetahuan tentang pemanfaatan tumbuhan ini merupakan warisan budaya daerah masing-masing berdasarkan pengalaman, pengetahuan dan keterampilan secara turun-temurun yang telah diwariskan oleh generasi sebelumnya, termasuk saat ini (Hutchinson, 2000). Jenis-jenis tumbuhan berkhasiat obat ini telah terbukti daya penyembuhannya sehingga tumbuhan obat yang ada harus dijaga serta dilestarikan oleh semua kalangan masyarakat. Jenis-jenis tumbuhan ini dapat dilihat pada Tabel 1.

\begin{tabular}{|c|c|c|c|c|c|c|c|c|}
\hline No & $\begin{array}{l}\text { Nama Umum, } \\
\text { Lokal dan } \\
\text { Nama Ilmiah }\end{array}$ & $\begin{array}{l}\text { Bagian } \\
\text { yang } \\
\text { Digunak }\end{array}$ & $\begin{array}{l}\text { Bahan } \\
\text { Tamb } \\
\text { ahan }\end{array}$ & $\begin{array}{c}\text { Jenis } \\
\text { Penyakit }\end{array}$ & $\begin{array}{c}\text { Cara } \\
\text { Pengolah } \\
\text { an }\end{array}$ & $\begin{array}{l}\text { Cara } \\
\text { Penggun } \\
\text { aan }\end{array}$ & $\begin{array}{l}\text { Waktu } \\
\text { Pengun } \\
\text { aan }\end{array}$ & $\begin{array}{l}\text { Lama } \\
\text { Peng } \\
\text { gunaa }\end{array}$ \\
\hline
\end{tabular}




\begin{tabular}{|c|c|c|c|c|c|c|c|c|}
\hline & & an & & & & & & $\mathrm{n}$ \\
\hline 1 & $\begin{array}{c}\text { Mangga } \\
\text { (Makas) } \\
\text { Mangifea indica }\end{array}$ & $\begin{array}{l}\text { Daun tua } \\
9 \text { lembar }\end{array}$ & $\begin{array}{l}\text { Air } 3 \\
\text { gelas }\end{array}$ & $\begin{array}{l}\text { Darah } \\
\text { tinggi }\end{array}$ & $\begin{array}{l}\text { Rebus } \\
\text { memakai } \\
\text { periuk } \\
\text { tanah } \\
\text { sampai } \\
\text { tersisa } 1 \\
\text { gelas }\end{array}$ & $\begin{array}{l}\text { Diminu } \\
\mathrm{m}\end{array}$ & $\begin{array}{l}\text { Pagi } \\
\text { dan } \\
\text { sore }\end{array}$ & $\begin{array}{l}7-14 \\
\text { Hari }\end{array}$ \\
\hline 2 & $\begin{array}{c}\text { Nangka } \\
\text { (Kulu) } \\
\text { Artocarpus } \\
\text { heterophyllus }\end{array}$ & $\begin{array}{c}\text { Kulit } \\
\text { batang } 3 \\
\text { buah }\end{array}$ & $\begin{array}{ll}\text { Air } 1 \\
\text { liter }\end{array}$ & $\begin{array}{l}\text { Darah } \\
\text { tinggi }\end{array}$ & Rebus & $\begin{array}{l}\text { Diminu } \\
\mathrm{m}\end{array}$ & $\begin{array}{l}\text { Pagi } \\
\text { dan } \\
\text { sore }\end{array}$ & $\begin{array}{l}\text { 7-14 } \\
\text { Hari }\end{array}$ \\
\hline 3 & $\begin{array}{c}\text { Kersen } \\
\text { (Kersen) } \\
\text { Muntingia } \\
\text { calabura L. }\end{array}$ & $\begin{array}{c}\text { Daun } \\
\text { dan buah }\end{array}$ & $\begin{array}{l}\text { Air } 3 \\
\text { gelas }\end{array}$ & $\begin{array}{l}\text { Gula } \\
\text { darah }\end{array}$ & $\begin{array}{l}\text { Direbus } \\
\text { hingga } \\
\text { tinggal } 1 \\
\text { gelas }\end{array}$ & $\begin{array}{l}\text { Diminu } \\
\mathrm{m}\end{array}$ & $\begin{array}{l}\text { Pagi } \\
\text { dan } \\
\text { sore }\end{array}$ & $\begin{array}{c}1-7 \\
\text { Hari }\end{array}$ \\
\hline 4 & $\begin{array}{c}\text { Patikan Cina } \\
\text { (Baih kuna } \\
\text { mea) } \\
\text { Euphorbia } \\
\text { thymifolia L. }\end{array}$ & $\begin{array}{l}\text { Akar, } \\
\text { batang, } \\
\text { daun }\end{array}$ & Air & Usus & $\begin{array}{l}\text { Dicuci } \\
\text { lalu } \\
\text { Dimakan } \\
\text { langsung }\end{array}$ & Dimakan & $\begin{array}{l}\text { Ketika } \\
\text { merasa } \\
\text { sakit }\end{array}$ & $\begin{array}{c}1-3 \\
\text { Hari }\end{array}$ \\
\hline 5 & $\begin{array}{c}\text { Gandarusa } \\
\text { (Gandarusa) } \\
\text { Justicia } \\
\text { gendarussa } \mathrm{L} .\end{array}$ & Daun & $\begin{array}{l}\text { Kapur } \\
1 / 2 \\
\text { sendo } \\
\mathrm{k}\end{array}$ & Kudis & $\begin{array}{l}\text { Ditumbuk } \\
\text { dengan } \\
\text { kapur }\end{array}$ & Ditempel & $\begin{array}{l}\text { Pagi } \\
\text { Hari }\end{array}$ & $\begin{array}{l}1-14 \\
\text { Hari }\end{array}$ \\
\hline 6 & $\begin{array}{l}\text { Tapak Liman } \\
\text { (Aus leha) } \\
\text { Elephantopus } \\
\text { scaber L. }\end{array}$ & Akar & $\begin{array}{l}\text { Air 5 } \\
\text { Gelas } \\
\text { Dagin } \\
\text { g } \\
\text { Ayam } \\
\end{array}$ & Lever & Direbus & $\begin{array}{l}\text { Diminu } \\
\mathrm{m}\end{array}$ & $\begin{array}{l}\text { Pagi } \\
\text { dan } \\
\text { malam }\end{array}$ & $\begin{array}{l}1-14 \\
\text { Hari }\end{array}$ \\
\hline 7 & $\begin{array}{c}\text { Jambu biji } \\
\text { (Kujawas) } \\
\text { Psidium } \\
\text { guajava } \mathrm{L} .\end{array}$ & $\begin{array}{c}\text { Kulit } \\
\text { batang } \\
\text { dan } \\
\text { pucuk } \\
\text { daun }\end{array}$ & $\begin{array}{l}\text { Air 3 } \\
\text { Gelas } \\
\text { dan } \\
\text { pinan } \\
\text { g }\end{array}$ & $\begin{array}{l}\text { Sakit } \\
\text { perut }\end{array}$ & $\begin{array}{l}\text { Kulit } \\
\text { batang di } \\
\text { rebus } \\
\text { dengan } \\
\text { pinang, } \\
\text { Dipetik } \\
\text { langsung } \\
\text { pakai } \\
\text { mulut } \\
\end{array}$ & $\begin{array}{l}\text { Diminu } \\
\text { m dan } \\
\text { makan } \\
\text { langsung } \\
\text { pucuk } \\
\text { daun } \\
\text { muda }\end{array}$ & $\begin{array}{l}\text { Ketika } \\
\text { merasa } \\
\text { sakit }\end{array}$ & $\begin{array}{c}1-3 \\
\text { Hari }\end{array}$ \\
\hline 8 & $\begin{array}{c}\text { Bunga bakung } \\
\text { (Baih pen mea) } \\
\text { Crinum } \\
\text { asiaticum }\end{array}$ & Umbi & $\begin{array}{l}\text { Minya } \\
\mathrm{k} \\
\text { kelapa }\end{array}$ & Hernia & $\begin{array}{l}\text { Diris tipis } \\
\text { tambahka } \\
\mathrm{n} \text { sedikit } \\
\text { minyak } \\
\text { kelapa }\end{array}$ & Ditempel & $\begin{array}{l}\text { Setiap } \\
\text { pagi }\end{array}$ & $\begin{array}{c}1-3 \\
\text { Hari }\end{array}$ \\
\hline 9 & $\begin{array}{c}\text { Sirsak } \\
\text { (Anon blai) } \\
\text { Annona } \\
\text { muricata Linn }\end{array}$ & $\begin{array}{l}\text { Daun } \\
\text { tua ganjil } \\
3,5,7 \\
\text { atau } 9 \\
\text { lembar }\end{array}$ & $\begin{array}{l}\text { Air } 3 \\
\text { gelas }\end{array}$ & Lambung & $\begin{array}{l}\text { Rebus } \\
\text { dengan } \\
\text { air di } \\
\text { periuk } \\
\text { tanah } \\
\text { sampai } \\
\text { tinggal } 1 \\
\text { gelas }\end{array}$ & $\begin{array}{l}\text { Diminu } \\
\mathrm{m}\end{array}$ & $\begin{array}{l}\text { Pagi, } \\
\text { siang } \\
\text { malam }\end{array}$ & $\begin{array}{l}7-14 \\
\text { Hari }\end{array}$ \\
\hline 10 & $\begin{array}{c}\text { Kamboja } \\
\text { (Bunga tai mea) } \\
\text { Adenium } \\
\end{array}$ & $\begin{array}{c}\text { Kulit } \\
\text { batang }\end{array}$ & $\begin{array}{c}\text { Air } \\
\text { secuk } \\
\text { upnya }\end{array}$ & Keputihan & $\begin{array}{l}\text { Rebus } \\
\text { dengan } \\
\text { Air }\end{array}$ & $\begin{array}{l}\text { Diminu } \\
\mathrm{m}\end{array}$ & $\begin{array}{l}\text { Pagi, } \\
\text { siang, } \\
\text { sore } \\
\end{array}$ & $\begin{array}{c}1-7 \\
\text { Hari }\end{array}$ \\
\hline
\end{tabular}




\begin{tabular}{|c|c|c|c|c|c|c|c|c|}
\hline & Obesum & & & & & & & \\
\hline 11 & $\begin{array}{c}\text { Benalu } \\
\text { (Kai ap dapa) } \\
\text { Loranthus } s p\end{array}$ & Daun & $\begin{array}{c}\text { Air } \\
\text { secuk } \\
\text { upnya } \\
\end{array}$ & Lever & $\begin{array}{l}\text { Rebus } \\
\text { dengan } \\
\text { air }\end{array}$ & $\begin{array}{l}\text { Diminu } \\
\text { m dan } \\
\text { mandi }\end{array}$ & $\begin{array}{l}\text { Pagi } \\
\text { dan } \\
\text { sore }\end{array}$ & $\begin{array}{c}1-7 \\
\text { Hari }\end{array}$ \\
\hline 12 & $\begin{array}{c}\text { Jarak pagar } \\
\text { (Pokaes muti) } \\
\text { Jatropha curcas }\end{array}$ & $\begin{array}{c}\text { Kulit } \\
\text { batang }\end{array}$ & $\begin{array}{l}\text { Air } 3 \\
\text { gelas }\end{array}$ & $\begin{array}{l}\text { Sakit } \\
\text { perut }\end{array}$ & $\begin{array}{l}\text { Rebus } \\
\text { dengan } \\
\text { air di } \\
\text { periuk } \\
\text { tanah }\end{array}$ & $\begin{array}{l}\text { Diminu } \\
\mathrm{m}\end{array}$ & $\begin{array}{l}\text { Pagi, } \\
\text { siang, } \\
\text { malam }\end{array}$ & $\begin{array}{l}1-3 \\
\text { hari }\end{array}$ \\
\hline 13 & $\begin{array}{c}\text { Patikan kebo } \\
\text { (Lilita mea) } \\
\text { Euphorbia hirta } \\
\text { L. }\end{array}$ & $\begin{array}{c}\text { Daun } \\
\text { dan } \\
\text { batang }\end{array}$ & Air & $\begin{array}{l}\text { Sakit } \\
\text { perut }\end{array}$ & $\begin{array}{l}\text { Dicuci } \\
\text { lalu } \\
\text { dimakan } \\
\text { langsung }\end{array}$ & Dimakan & $\begin{array}{l}\text { Ketika } \\
\text { merasa } \\
\text { sakit }\end{array}$ & $\begin{array}{c}1-2 \\
\text { Hari }\end{array}$ \\
\hline 14 & $\begin{array}{l}\text { Kawista batu } \\
\text { (Bilat) } \\
\text { Feroniella } \\
\text { lucida }\end{array}$ & $\begin{array}{l}\text { Buah } \\
\text { muda }\end{array}$ & $\begin{array}{c}\text { Air } \\
\text { secuk } \\
\text { upnya }\end{array}$ & Gondok & $\begin{array}{l}\text { Rebus } \\
\text { dengan } \\
\text { air }\end{array}$ & $\begin{array}{l}\text { Diminu } \\
\mathrm{m} \text { dan } \\
\text { buahnya } \\
\text { digulung } \\
\text { pada } \\
\text { area } \\
\text { yang } \\
\text { sakit }\end{array}$ & $\begin{array}{l}\text { Pagi } \\
\text { dan } \\
\text { sore }\end{array}$ & $\begin{array}{c}1-7 \\
\text { Hari }\end{array}$ \\
\hline 15 & $\begin{array}{c}\text { Pepaya } \\
\text { (Kaut) } \\
\text { Carica papaya } \\
\text { L }\end{array}$ & Daun & $\begin{array}{l}\text { Air } 5 \\
\text { gelas }\end{array}$ & $\begin{array}{l}\text { Malaria } \\
\text { dan panas }\end{array}$ & $\begin{array}{l}\text { Rebus } \\
\text { dengan } \\
\text { air di } \\
\text { periuk } \\
\text { tanah }\end{array}$ & $\begin{array}{l}\text { Diminu } \\
\mathrm{m}\end{array}$ & $\begin{array}{l}\text { Pagi, } \\
\text { siang, } \\
\text { malam }\end{array}$ & $\begin{array}{c}3-7 \\
\text { Hari }\end{array}$ \\
\hline 16 & $\begin{array}{c}\text { Trengguli } \\
\text { (Naen) } \\
\text { Cassia fistula } \mathrm{L} .\end{array}$ & $\begin{array}{c}\text { Daun } \\
\text { ganjil } \\
3,5,7 \\
\text { atau } 9 \\
\text { lembar }\end{array}$ & $\begin{array}{c}\text { Air } \\
\text { secuk } \\
\text { upnya }\end{array}$ & $\begin{array}{l}\text { Tumor } \\
\text { kandunga } \\
\mathrm{n}\end{array}$ & $\begin{array}{l}\text { Rebus } \\
\text { dengan } \\
\text { air di } \\
\text { periuk } \\
\text { tanah }\end{array}$ & $\begin{array}{l}\text { Diminu } \\
\mathrm{m} \quad \text { air } \\
\text { nya, } \\
\text { daun nya } \\
\text { ditempel }\end{array}$ & $\begin{array}{l}\text { Pagi } \\
\text { dan } \\
\text { sore }\end{array}$ & $\begin{array}{c}3-7 \\
\text { Hari }\end{array}$ \\
\hline 17 & $\begin{array}{l}\text { Cantel } \\
\text { (Masin) } \\
\text { Sorghum } \\
\text { bicolor }\end{array}$ & $\begin{array}{c}\text { Biji } \\
\text { kering }\end{array}$ & $\begin{array}{l}\text { Air } \\
\text { hanga } \\
\mathrm{t} \quad 1 \\
\text { gelas }\end{array}$ & $\begin{array}{l}\text { Kanker } \\
\text { payudara } \\
\text { dan tumor }\end{array}$ & $\begin{array}{l}\text { Digoreng, } \\
\text { ditumbuk } \\
\text { halus } \\
\text { tambahka } \\
\mathrm{n} \quad \text { air } \\
\text { hangat }\end{array}$ & $\begin{array}{l}\text { Airnya } \\
\text { diminum } \\
\text { ampasny } \\
\text { a } \\
\text { ditempel }\end{array}$ & $\begin{array}{l}\text { Pagi } \\
\text { dan } \\
\text { sore }\end{array}$ & $\begin{array}{c}3-7 \\
\text { Hari }\end{array}$ \\
\hline 18 & $\begin{array}{c}\text { Kelor } \\
\text { (Utapo) } \\
\text { Moringa } \\
\text { oleifera L }\end{array}$ & Batang & $\begin{array}{l}\text { Air } 3 \\
\text { gelas }\end{array}$ & $\begin{array}{l}\text { Sakit saat } \\
\text { bersalin } \\
\text { Pega linu } \\
\text { dan } \\
\text { rematik }\end{array}$ & $\begin{array}{l}\text { Direbus } \\
\text { dengan } \\
\text { Air }\end{array}$ & $\begin{array}{l}\text { Diminu } \\
\mathrm{m}\end{array}$ & $\begin{array}{l}\text { Pada } \\
\text { saat } \\
\text { sakit }\end{array}$ & $\begin{array}{c}1-3 \\
\text { Hari }\end{array}$ \\
\hline 19 & $\begin{array}{c}\text { Flamboyan } \\
\text { (Sepe) } \\
\text { Delonix regia }\end{array}$ & $\begin{array}{c}\text { Batang } \\
\text { kecil }\end{array}$ & Air & Ginjal & $\begin{array}{l}\text { Rebus } \\
\text { dengan } \\
\text { air di } \\
\text { periuk } \\
\text { tanah }\end{array}$ & $\begin{array}{l}\text { Diminu } \\
\mathrm{m}\end{array}$ & $\begin{array}{l}\text { Pagi, } \\
\text { siang, } \\
\text { malam }\end{array}$ & $\begin{array}{c}1-7 \\
\text { Hari }\end{array}$ \\
\hline 20 & $\begin{array}{l}\text { Binahong } \\
\text { (Binahong) } \\
\text { Anredera } \\
\text { cordifolia }\end{array}$ & Daun & Air & Lambung & $\begin{array}{l}\text { Rebus } \\
\text { dengan } \\
\text { air }\end{array}$ & $\begin{array}{l}\text { Diminu } \\
\mathrm{m}\end{array}$ & Pagi & $\begin{array}{c}1-3 \\
\text { Hari }\end{array}$ \\
\hline 21 & $\begin{array}{c}\text { Terong asam } \\
\text { (Mhili) } \\
\text { Solanum }\end{array}$ & Akar & Air & Keputihan & $\begin{array}{l}\text { Rebus } \\
\text { dengan } \\
\text { air }\end{array}$ & $\begin{array}{l}\text { Diminu } \\
\mathrm{m}\end{array}$ & $\begin{array}{l}\text { Pagi } \\
\text { dan } \\
\text { sore }\end{array}$ & $\begin{array}{c}1-3 \\
\text { Hari }\end{array}$ \\
\hline
\end{tabular}




\begin{tabular}{|c|c|c|c|c|c|c|c|c|}
\hline & indicum & & & & & & & \\
\hline 22 & $\begin{array}{c}\text { Pulai } \\
\text { (Dete) } \\
\text { Alstonia } \\
\text { scholaris L. }\end{array}$ & $\begin{array}{c}\text { Kulit } \\
\text { batang }\end{array}$ & $\begin{array}{l}\text { Air } 5 \\
\text { gelas }\end{array}$ & $\begin{array}{l}\text { Malaria } \\
\text { dan panas } \\
\text { tinggi }\end{array}$ & $\begin{array}{l}\text { Rebus } \\
\text { dengan } \\
\text { air di } \\
\text { peiuk } \\
\text { tanah }\end{array}$ & $\begin{array}{l}\text { Diminu } \\
\mathrm{m}\end{array}$ & $\begin{array}{l}\text { Pagi, } \\
\text { siang } \\
\text { malam }\end{array}$ & $\begin{array}{c}3-7 \\
\text { Hari }\end{array}$ \\
\hline 23 & $\begin{array}{c}\text { Kumis kucing } \\
\text { (Kumis kucing) } \\
\text { Orthosiphon } \\
\text { aristatus }\end{array}$ & Daun & Air & $\begin{array}{l}\text { Kencing } \\
\text { batu dan } \\
\text { kencing } \\
\text { manis }\end{array}$ & $\begin{array}{l}\text { Rebus } \\
\text { dengan } \\
\text { air }\end{array}$ & diminum & $\begin{array}{l}\text { Pagi, } \\
\text { siang, } \\
\text { malam }\end{array}$ & $\begin{array}{l}1-14 \\
\text { Hari }\end{array}$ \\
\hline 24 & $\begin{array}{l}\text { Meniran } \\
\text { (Blua puti) } \\
\text { Phyllanthus } \\
\text { niruri L. }\end{array}$ & Daun & Air & $\begin{array}{l}\text { Kencing } \\
\text { batu dan } \\
\text { kencing } \\
\text { manis }\end{array}$ & $\begin{array}{l}\text { Rebus } \\
\text { dengan } \\
\text { air } 3 \text { gelas } \\
\text { hingga } \\
\text { sisa } \\
\text { gelas }\end{array}$ & diminum & $\begin{array}{l}\text { Pagi, } \\
\text { siang } \\
\text {,malam }\end{array}$ & $\begin{array}{c}3-7 \\
\text { Hari }\end{array}$ \\
\hline 25 & $\begin{array}{c}\text { Ginseng } \\
\text { (Ginseng) } \\
\text { Talinum } \\
\text { paniculatum }\end{array}$ & Daun & - & Lambung & Dikunyah & $\begin{array}{l}\text { Diamaka } \\
\mathrm{n}\end{array}$ & $\begin{array}{l}\text { Ketika } \\
\text { merasa } \\
\text { sakit }\end{array}$ & $\begin{array}{c}1-3 \\
\text { Hari }\end{array}$ \\
\hline 26 & $\begin{array}{l}\text { Anggrek putih } \\
\text { (Toep muti) } \\
\text { Phalaenopsis sp }\end{array}$ & Batang & $\begin{array}{l}\text { Air } \\
\text { dan } \\
\text { bawan } \\
\text { g } \\
\text { merah } \\
\end{array}$ & $\begin{array}{l}\text { Sakit } \\
\text { pimggang }\end{array}$ & $\begin{array}{l}\text { Rebus } \\
\text { dengan } \\
\text { air }\end{array}$ & $\begin{array}{l}\text { Diminu } \\
\mathrm{m}\end{array}$ & $\begin{array}{l}\text { Pagi, } \\
\text { siang, } \\
\text { sore }\end{array}$ & $\begin{array}{c}\text { 1-3 } \\
\text { Hari }\end{array}$ \\
\hline 27 & $\begin{array}{l}\text { Kayu ular } \\
\text { (Mhaba) } \\
\text { Strychnos } \\
\text { lucida } \text { R.Br }\end{array}$ & $\begin{array}{c}\text { Kulit } \\
\text { batang }\end{array}$ & Air & Malaria & $\begin{array}{l}\text { Rebus } \\
\text { dengan } \\
\text { air }\end{array}$ & $\begin{array}{l}\text { Diminu } \\
\mathrm{m}\end{array}$ & $\begin{array}{l}\text { Pagi } \\
\text { dan } \\
\text { sore }\end{array}$ & $\begin{array}{c}3-7 \\
\text { Hari }\end{array}$ \\
\hline 28 & $\begin{array}{c}\text { Sirih } \\
\text { (Malus) } \\
\text { Piper betle L. }\end{array}$ & Daun & Air & $\begin{array}{l}\text { Keputihan } \\
\text { Mata } \\
\text { rabun }\end{array}$ & $\begin{array}{l}\text { Rebus } \\
\text { dengan } \\
\text { air }\end{array}$ & $\begin{array}{l}\text { Dibasuh } \\
\text { pada } \\
\text { area } \\
\text { kewanita } \\
\text { an. } \\
\text { Dibasuh } \\
\text { pada } \\
\text { mata. }\end{array}$ & $\begin{array}{l}\text { Pagi } \\
\text { dan } \\
\text { sore } \\
\text { Pagi } \\
\text { hari }\end{array}$ & $\begin{array}{c}1-7 \\
\text { Hari }\end{array}$ \\
\hline 29 & $\begin{array}{c}\text { Ajeran } \\
\text { (Seman } \\
\text { Nhunga) } \\
\text { Bidens pilosa L. }\end{array}$ & Daun & $\begin{array}{l}\text { Gara } \\
\mathrm{m}\end{array}$ & $\begin{array}{l}\text { Luka } \\
\text { sayatan }\end{array}$ & $\begin{array}{l}\text { Di } \\
\text { tumbuk } \\
\text { dengan } \\
\text { garam }\end{array}$ & $\begin{array}{l}\text { Di } \\
\text { temple } \\
\text { pada } \\
\text { bagian } \\
\text { luka }\end{array}$ & $\begin{array}{l}\text { Pada } \\
\text { saat } \\
\text { terkena } \\
\text { luka }\end{array}$ & $\begin{array}{rr}1-3 & \mathrm{H} \\
& \mathrm{a} \\
& \mathrm{ri}\end{array}$ \\
\hline 30 & $\begin{array}{l}\text { Tapak kuda } \\
\text { (Ahloet leha) } \\
\text { Ipomoea pes- } \\
\text { caprae L. }\end{array}$ & Akar & - & $\begin{array}{l}\text { Pendaraha } \\
\mathrm{n}\end{array}$ & Dikunyah & $\begin{array}{l}\text { Diurut } \\
\text { pada } \\
\text { kaki }\end{array}$ & $\begin{array}{l}\text { Pada } \\
\text { saat } \\
\text { sakit }\end{array}$ & $\begin{array}{c}1-3 \\
\text { Hari }\end{array}$ \\
\hline 31 & $\begin{array}{l}\text { Kapuk hutan } \\
\text { (Dengen alas) } \\
\text { Bombax } \\
\text { malabarica }\end{array}$ & $\begin{array}{c}\text { Kulit } \\
\text { pohon } \\
20-30 \\
\text { potong }\end{array}$ & $\begin{array}{c}\text { Air } \\
\text { Secuk } \\
\text { upnya }\end{array}$ & $\begin{array}{l}\text { Patah } \\
\text { tulang } \\
\text { atau } \\
\text { kecelakaa } \\
\mathrm{n}\end{array}$ & $\begin{array}{l}\text { Dimasak } \\
\text { dengan } \\
\text { air }\end{array}$ & $\begin{array}{l}\text { Diminu } \\
\mathrm{m} \text { dan } \\
\text { kompres }\end{array}$ & $\begin{array}{l}\text { Pagi } \\
\text { dan } \\
\text { sore }\end{array}$ & $\begin{array}{c}14-30 \\
\text { Hari }\end{array}$ \\
\hline
\end{tabular}

Sumber: Hasil Penelitian, 2017

Diagram 1 dan 2 menunjukan bahwa pada umumnya masyarakat di Desa Huilelot dan Desa Uiasa lebih banyak menggunakan bagian organ daun (12 jenis) tumbuhan berkhasiat obat untuk menyembuhkan berbagai macam penyakit. Handayani (2003) 
mengatakan daun merupakan salah satu organ terpenting bagi tumbuhan karena pada daun terdapat zat hijau daun (klorofil) yang sangat bermanfaat bagi tumbuhan sebagai organ fotosintesis. Daun juga berperan sebagai tempat pertukaran gas (pernapasan), sebagai tempat proses transpirasi dan alat perkembangbiakan vegetatif. Tumbuhan obat yang ditemukan berdasarkan sebaran lokasi tumbuh di pekarangan adalah Mangga, nangka, patikan cina, gandarusa, jambu biji, sirsak, kamboja, papaya, kelor, binahong, terong asam, kumis kucing, meniran, ginseng, sirih, ajeran. Tumbuhan obat yang di temukan di pinggir jalan adalah kersen, jarak pagar. Tumbuhan obat yang ditemukan di kebun adalah bunga bakung, patikan kebo, cantel. Tumbuhan obat yang ditemukan di hutan adalah tapak liman, benalu, kawista batu, trengguli, flamboyan, pulai, anggrek putih, kayu ular, kapuk hutan Diagram 3 dan 4 menunjukan tentang organ yang digunakan dan cara pengelolaan. Salah satu jenis tumbuhan yang direbus yaitu daun kumis kucing yang digunakan dalam menyembuhkan penyakit kencing batu. Jenis tumbuhan lain dapat direbus mangga, nangka, kersen, tapak liman, jambu biji, sirsak, kamboja, benalu, jarak pagar, kawista batu, papaya, trengguli, flamboyan, binahong, terong kuning, pulai, meniran, anggrek pitih, kayu ular, sirih dan kapuk hutan. Jenis yang direbus dan diblender adalah Kelor. Jenis tumbuhan berkhasiat obat yang di tumbuk yaitu daun gandarusa, biji cantel, daun ajeran, dimakan langsung ada ginseng dan patikan kebo, diiris umbi dari bunga bakung, dikunyah lalu diurut adalah akar tapak kuda.

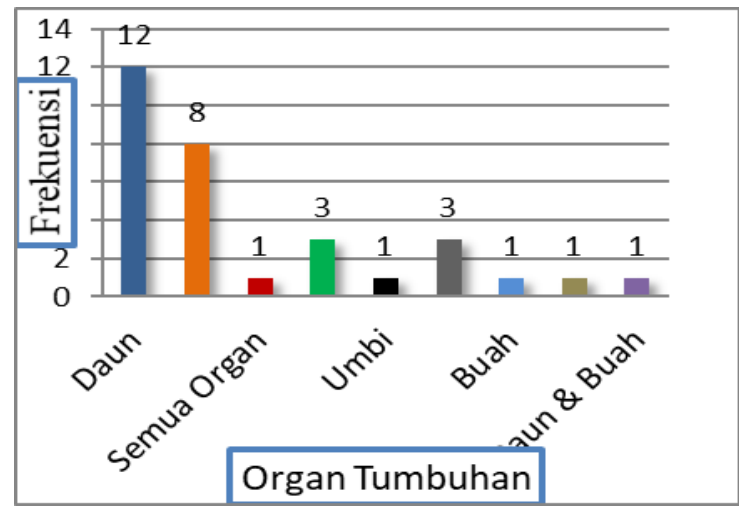

Gambar 2. Diagram Organ Tumbuhan yang Digunakan

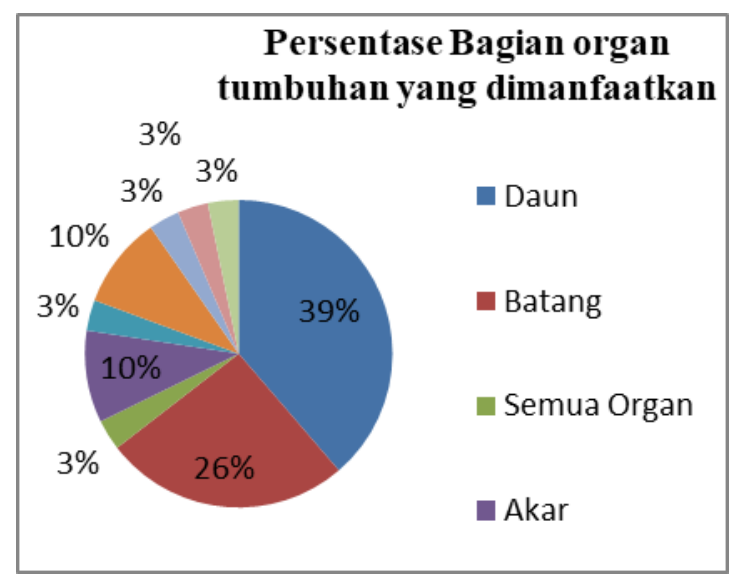

Gambar 3. Diagram Presentase Bagian Organ Tumbuhan 


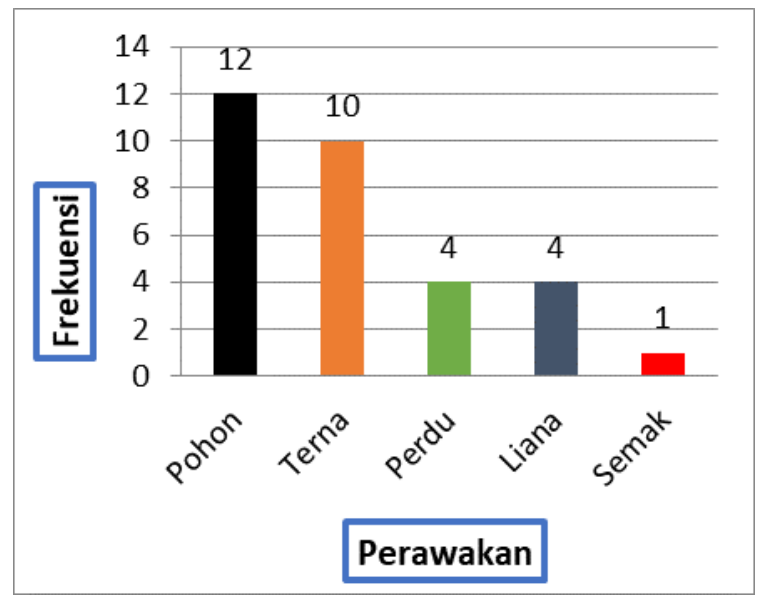

Gambar 4. Diagram Organ Tumbuhan yang Digunakan

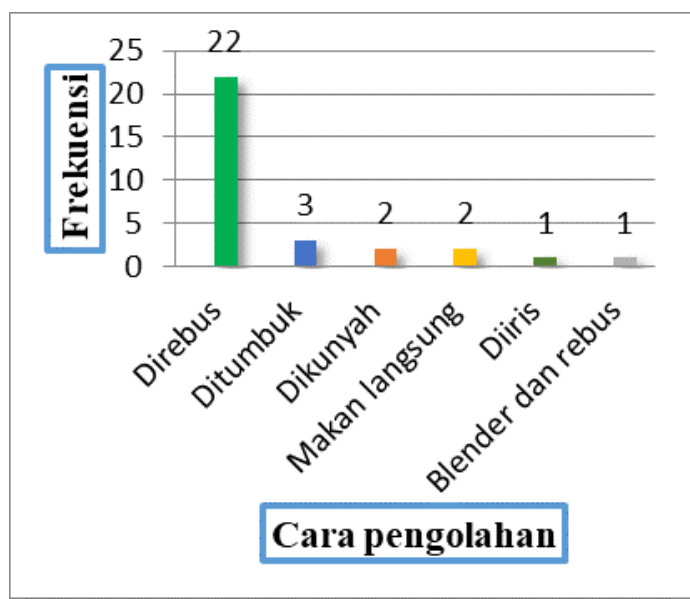

\section{Gambar 5. Diagram PerawakanTumbuhan Berkhasiat Obat}

Beberapa manfaat klorofil bagi tubuh manusia, antara lain: membantu proses pembentukan sel-sel darah merah serta dapat mencegah anemia, membantu mengtrol rasa lapar, mempercepat proses penyembuhan luka, menghilangkan racun dalam tubuh (proses detoksifikasi), melindungi DNA dalam tubuh, sebagai antioksidan yang ampuh, membantu dalam proses terapi pada pasien penyakit kanker, dapat mengobati bengkak dan kemerahan pada kulit, menjaga kesehatan sistem pencernaan, mencegah insomnia, meningkatkan sistem kekebalan tubuh, membantu proses pembekuan darah, menurunkan resiko batu ginjal, menjaga keseimbangan hormon dalam tubuh, mencegah resiko gangguan pankreas.

Menurut Handayani (2003) menambahkan bahwa daun merupakan bagian/organ tumbuhan yang paling banyak digunakan sebagai obat tradisional karena daun pada umumnya bertekstur lunak sebab mempunyai kandungan air yang tinggi (70-80\%), selain itu daun merupakan tempat akumulasi fotosistesis yang mengandung unsur-unsur zat organik dalam menyembuhkan berbagai penyakit. Menurut Siswanto (2003), pemanfaatan tumbuhan obat tradisional yang mencakup berbagai organ tumbuhan yang dijadikan sebagai obat dapat diambil seluruh atau sebagian tubuhnya untuk diramu sebagai obat tradisional. Alasan responden menggunakan daun karena mudah diambil dan banyak didapatkan hal ini juga sesuai pendapat (Fakhrozi, 2009) yang menyatakan 
bahwa daun juga memilki regenerasi yang tinggi untuk kembali bertunas dan tidak memberi pengaruh yang besar terhadap pertumbuhan suatu tanaman meskipun daun merupakan tempat fotosintesis. Pada daun jug aterdapat minyak atsiri, di mana minyak atsiri adalah campuran berbagai pesenyawaan organik yang mudah menguap,mudah larut dalam pelarut organik serta mempunyai aroma khas sesuai dengan jenis tanamannya. Menurut Gasmalini (dalam Penelitiannya Sembring dkk,) minyak atsiri dapat digunakan sebagai obat-obatan, parfum, minuman dan penyedap makanan serta pestisida. Kandungan minyak atsiri pun dapat mengandung zat antibakteri yang efektif untuk membunuh bakteri misalnya pda tangan (Cahyani, 2014)

Bagian-bagian tumbuhan yang diramu sebagai obat adalah: batang, daun, bunga, buah, biji, akar maupun getah. Pemanfaatan bagian/organ tumbuhan untuk setiap jenis tumbuhan obat yang dilakukan oleh masyarakat di Desa Huilelot dan Desa Uiasa tidak selalu sama yaitu tergantung penyakit apa yang akan disembuhkan, pengetahuan masing-masing pengobat dan biasanya bagian tumbuhan yang memiliki khasiat tertentu. Jika dibandingkan dengan penelitian sebelumnya Duka (2016) yang dilakukan di Desa Lendola yang terletak di Kecamatan Teluk Mutiara Kabupaten Alor yang menemukan 33 jenis tumbuhan obat yang berkhasiat obat dan Willa (2017) di Kecamatan Sabu Liae (Desa Raerobo, Desa Dainao, Desa Mehona) Kabupaten Sabu Raijua menemukan 27 jenis tumbuhan yang berkhasiat sebagai obat. Hal ini menunjukan bahwa ketergantungan masyarakat pada tumbuhan obat masih tinggi disetiap daerah dan perlu dilestarikan sebagai salah satu budaya pengobatan tradisional dari generasi ke generasi berikut. Bagian-bagain tumbuhan yang ditemukan juga diperkuat oleh penelitian Sudibyo (2001), melaporkan bahwa kira-kira 80\% orang Indonesia merawat kesehatannya dengan menggunakan obat-obatan tradisional yaitu meminum ramuan secara teratur. Masyarakat khususnya yang tinggal di desa masih memanfaatkan tumbuhan obat secara langsung yaitu berupa simplisia (masih berupa daun, kulit, akar, batang, bunga atau buah). Hal ini disesuaikan dengan jenis penyakit yang akan diobati dan terkadang hanya satu bagian organ tumbuhan yang diambil atau digunakan. Namun, ada juga organ tumbuhan yang digunakan bukan hanya satu tetapi lebih. Contohnya pada tumbuhan jambu biji dan tumbuhan kelor yang bisa digunakan sebagai obat yaitu daun dan kulit batang. Pemanfaatan bagian organ tumbuhan yang berkhasiat obat oleh pengobat tradisional merupakan suatu pengalaman yang didapat dari orang tua secara turun-temurun.

Dalam mengolah ramuan juga membutuhkan waktu yang cukup lama berkisar antara 15 menit hingga 1 jam dengan tujuan agar ramuan yang digunakan benar-benar berkhasiat. Jika pengolahan tumbuhan dilakukan melalui proses rebusan maka senyawasenyawa yang terkandung pada organ tumbuhan akan keluar dan tercampur dengan air atau larut dalam air. Semakin lama proses perebusan yang dilakukan maka semakin banyak senyawa yang ada pada organ tumbuhan akan mengalami penguapan sehingga kualitas ramuan dari organ tumbuhan akan semakin berkhasiat (Arisandi dan Andriani, 2009).

Masyarakat di Desa Huilelot dan Desa Uiasa lebih banyak memperolah Tumbuhan obat yang tumbuh secara liar daripada yang dibudidayakan. Hal ini menunjukan bahwa masyarakat masih ketersediaan tumbuhan obat sangat melimpah di hutan. Berdasarkan hasil wawancara dengan salah seorang pengobat diketahui bahwa alasan kenapa pengobat tidak membudidayakan tumbuhan obat di sekitar rumah mereka karena adanya pantangan yang dapat membuat khasiat dari tumbuhan obat tersebut tidak maksimal. Masyarakat di Desa Huilelot dan Desa Uiasa memiliki cara pengolahan 
tumbuhan obat yang berbeda-beda, dan juga tidak menggunakan semua organ tumbuhan tetapi hanya menggunakan salah satu ataupun beberapa bagian dari masingmasing tumbuhan sesuai dengan penyakit yang diderita dan juga dengan cara pengolahan yang berbeda pula. Cara pengolahan tumbuhan yang berkhasiat obat serta jenis-jenis penyakit yang dapat disembuhkan. Bagian-bagian tumbuhan yang diramu sebagai obat adalah: batang, daun, bunga, buah, biji, akar maupun getah. Pemanfaatan bagian/organ tumbuhan untuk setiap jenis tumbuhan obat yang dilakukan oleh masyarakat di Desa Huilelot dan Desa Uiasa tidak selalu sama yaitu tergantung penyakit apa yang akan disembuhkan, pengetahuan masing-masing pengobat dan biasanya bagian tumbuhan yang memiliki khasiat tertentu. Hal ini menunjukkan bahwa pengetahuan masyarakat khususnya pengobat tradisional tentang alasan penggunaan bagian tumbuhan yang berkhasiat obat sangat terbatas karena sesuai dengan pengetahuan masing-masing. Hal ini menunjukkan bahwa pengetahuan masyarakat khususnya pengobat tradisional tentang alasan penggunaan bagian tumbuhan yang berkhasiat obat sangat terbatas karena sesuai dengan pengetahuan masing-masing.

\section{KESIMPULAN DAN SARAN}

\section{Kesimpulan}

Berdasarkan hasil penelitian maka dapat disimpulkan bahwa : Jenis tumbuhan obat yang dimanfaatkan sebagai obat tradisional di Desa Huilelot dan Desa Uiasa berjumlah 31 spesies. Bagian/ organ tumbuhan yang digunakan yaitu daun, akar, umbi, buah, kulit, batang, biji dan semua organ. Bagian/organ yang sering di gunakan yaitu daun. Penyakitpenyakit yang dapat disembuhkan dengan menggunakan tumbuhan obat adalah Darah tinggi, gula darah, usus, kudis, hernia, lever, keputihan, sakit perut, gondok, tumor, kangker, lambung, ginjal, kencing batu, kencing manis, sakit pinggang, sakit bersalin, luka sayatan, malaria, pendarahan, panas dan patah tulang atau kecelakaan. Cara pengolahan yaitu direbus, ditumbuk, dikunyah, diiris, siblender dan dimakan langsung. Cara pengolahan yang sering digunakan adalah dengan cara direbus. Tumbuhan obat yang tumbuh liar antara sebanyak 19 jenis dan tumbuhan obat yang dibudidaya sebanyak 12 jenis.

\section{Saran}

Perlu dilanjutkan penelitian ini untuk mengetahui kandungan kimia yang terdapat pada tanaman obat sehingga menjadi rujukan dalam bidang farmasi.

\section{DAFTAR RUJUKAN}

Anief, M. (2002). Apa yang Perlu Diketahui tentang Obat. Gadjah Mada University Press. Yogyakarta.

Arisandi, Y. dan Andriani, Y. (2009). Khasiat Berbagai Tanaman untuk Pengobatan. Eska Media. Jakarta

Astria, Budhi S, dan Sisillia L. TT. (2014). Kajian Etnobotani Tumbuha Obat Pada Masyarakat Dusun Semoncol Kecamatan Balai Kabupaten Sanggau.400-406. Online. Tersedia: Jurnal.untan.ac.id. 
Cahyani, Novita Maylia Eka (2014). Daun Kemangi (Ocinum Cannum) Sebagai Alternatif Pembuatan Handsanitizier. Fakultas Kesehatan Masyarakat Universitas Jember, Indonesia. KEMAS 9 (2) (2014) 136-142 Jurnal Kesehatan Masyarakat. http://journal.unnes.ac.id/nju/index.php/kemas

Dalimarta, S. (2008). Ensiklopedia Tanaman Obat Indonesia. Dinamika Media: Jakarta.

Darsini, N.N. (2013). Analisis Keanekaragaman Jenis Tumbuhan Obat Tradisional Berkhasiat untuk Pengobatan Penyakit Saluran Kencing di Kecamatan Kintamani Kabupaten Bangli Provinsi Bali. Jurnal Bumi Lestari

Dalimartha, S. (2012). Herbal Indonesia Berkhasiat Bukti Ilmiah dan Cara Racik.Trubus: Bogor.

Duka, Y. (2016). Identifikasi Jenis Tumbuhan Berkhasiat Obat Di Desa Lendona Kabupaten Alor.UKAW.Kupang.

Hastuti, SD., Tokede $\mathrm{Mj}$ dan Maturbongs RA. (2002). Tumbuhan Obat Menurut Etnobotani Suku Biak. 4(1): 20-40. Online.Tersedia respository.unhas.ac.id.

Herbie, T. (2015).Kitab Tanaman Berkhasiat Obat 226 Tumbuhan Untuk Penyembuhan Penyakit dan Kebugaran Tubuh. Yogyakarta: Octopus Publishing House.

Handayani. 2003. Budaya Hukum dan Pemberdayaan Masyarakat dalam Pengelolaan Hutan.Jakarta.

Hidayat, S. dan Napitupulu, M. R. (2015).Kitab Tumbuhan Obat. AgrriFlo:Jakarta

Hutapea, J. 2000. Inventarisasi Tanaman Obat Indonesia Jilid1. Jakarta. Jurnal Inventaris-Tanaman-Obat-Indonesia-I-Jilid-1\#scribddi.pdf.

Hutchinson.( 2000). Tanaman Pekarangan Pilihan. Bandung : Salamadani.

Jefrin Sambara, Ni Nyoman Yuliani, Maria Yuniati. (2016). Pemanfaatan Tanaman Obat Tradisional Oleh Masyarakat Kelurahan Merdeka Kecamatan Kupang Timur. 259693-utilization-of-traditional-drug-plant-by-2fb67fc7.pdf. https://media.neliti.com/media/publications/259693-utilization-of-traditionaldrug-plant-by-2fb67fc7.pdf.

Kandowangko, Novri Y., Margaretha Solang, dan Jusna Ahmad. 2011. Kajian Etnobotani Tanaman Obat Oleh Masyarakat Kabupaten Bonebolango Provinsi Gorontalo. Laporan Penelitian. Universitas Negeri Gorontalo.

Natasapoetra. I. (2001). Khasiat Tanaman Obat. Penebar Swadaya. Jakarta.

Nursiyah,( 2013) Studi Deskriptif Tanaman Obat Tradisional yang Digunakan Orang Tua untuk Kesehatan Anak Usia Dini di Gugus Melatio Kecamatan Kalikajar Kabupaten Wonosobo. Skripsi.Fakultas Sains dan Teknologi.Universitas Islam Negeri Semarang. Semarang. Hal 9 - 10.

M, Hasanah, D Rusmin. (2006). Teknologi pengelolaan benih beberapa tanaman obat di Indonesia. Jurnal Litbang Pertanian, 2006 - 203.190.37.42.

Muti manda Dwi satyadi ni. Universitas Terbuka Repository. Optimalisasi Peran Sains dan Teknologi untuk Mewujudkan pemanfaatan tanaman obat untuk pencegahan dan pengobatan penyakit degeneratif. https://core.ac.uk/reader/198236982

Pramono, S. (2002). Kontribusi bahan obat alam dalam mengatasi krisis bahan obat di Indonesia, jurnal bahan alam Indonesia, 1 (1), 18-20.

Pratidina, R. (2016). Kajian Etnobotani Tumbuhan Obat Oleh Masyarakat Cjambu Di Kabupaten Bandung Barat. Universitas Pasudan. Bandung.

Sari, L.O.R.K. (2006). Pemanfaatan Obat Tradisional Dengan Pertimbangan dan Keamanan. Majalah Ilmu Kefarmasian.

Supardi, S., Jamal, S dan loupatty, A. (2003). Beberapa Faktor Yang Berhubungan dengan Penggunaan Obat Tradisional dalam Pengobatan Sendiri di Indonesia. 
Bul. Penel. Kesehatan. 31 (1) : 25-32. Jurnal Ilimiah Farmasi-UNSRAT . 5 (2) : 2302-2493.

Wales, (2010). Penggunaan obat tradisional oleh anggota rumah tangga. Media Litbangkes " edisi khusus obat asli Indonesia “

Widyastuti, Y. (2004). Penanganan Hasil Panen Tanaman Obat Komersil. Airlangga University Press.Halaman 17. Edisi Revisi. Surabaya

Willa, D. (2017). Studi Etnobotani Tumbuhan Obat Tradisional Di Masyarakat Kecamatan Sabu Liae ( Desa Raerobo,Desa Dainao, Desa Mehona,) Kabupaten Sabu RaiJua. UKAW. Kupang 